\title{
Current Concepts on Immunopathology of COVID-19 and Emerging Therapies
}

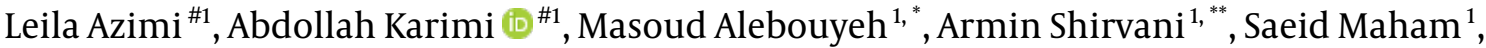 \\ Sedigheh Rafiei Tabatabaei ${ }^{1}$, Shahnaz Armin ${ }^{1}$, Fatemeh Fallah ${ }^{1}$, Maryam Rajabnejad ${ }^{1}$, Seyed Alireza \\ Fahimzad $^{1}$, Fariba Shirvani ${ }^{1}$ and Roxana Mansour Ghanaie ${ }^{1}$ \\ ${ }^{1}$ Pediatric Infections Research Center, Research Institute for Children's Health, Shahid Beheshti University of Medical Sciences, Tehran, Iran \\ "Corresponding author: Pediatric Infections Research Center, Research Institute for Children's Health, Shahid Beheshti University of Medical Sciences, Tehran, Iran. Email: \\ masoud.alebouyeh@gmail.com \\ "* Corresponding author: Research Institute for Children's Health, Shahid Beheshti University of Medical Sciences, Tehran, Iran. Email: arm.shirvani@gmail.com \\ \# These authors are contributed equally as the first author.
}

Received 2020 April 27; Revised 2020 June 11; Accepted 2020 June 12.

\begin{abstract}
Context: This scoping review tries to synthesize early findings on the immunopathogenicity of SARS-CoV-2 to assess the emerging therapies and vaccines by evaluating their impact based on the mechanism of pathogenicity.

Methods: The three databases of PubMed, Scopus, and Google Scholar were searched from January 1, 2020, to March 15, 2020. To extract the results from the studies, the content, thematic analysis method was used. In this method, the topics studied were coded in the articles, and then major topics related to the articles were determined. After identifying major issues, the contents of the articles were reviewed.

Results: A total of 2,250 articles were retrieved after deleting duplications, and after reviewing the thematic relevance, 45 of them were selected for the final analysis. Topics studied in the articles were classified into four main areas, including "virus entry inhibition and immune response", "vaccine and treatment targets", "genome structure similarity to other coronaviruses," and "pathogensis".

Conclusions: Results of this review showed that we have a long way to develop an effective and safe vaccine due to the structural and behavioral complexities of this virus. In the meantime, the scientific community should use results of megatrials, but until their accomplishing them, we have to use results of systematic reviews of randomized controlled trials.
\end{abstract}

Keywords: SARS-CoV-2, COVID-19, Pathogenesis, Vaccine, Treatment

\section{Context}

The World Health Organization declared COVID-19 as a pandemic by March 11, 2020. The disease has become a global public health concern, affecting more than 7,000,000 cases and causing 414,000 deaths globally (1-3). COVID-19 is caused by severe acute respiratory syndrome coronavirus 2 (SARS-CoV-2) that belongs to a family of RNA beta-coronavirus $2 \mathrm{~b}$ lineage $(3,4)$. This new coronavirus may cause coronavirus disease 2019 (COVID-19) that is accompanied by numerous symptoms, including pneumonia, dry cough, fever, myalgia, lymphopenia, and breathing difficulty (3-5). The virus was first detected in Wuhan, China, in early December 2019 (4).

SARS-CoV-2 shows genomic structural similarities to other coronavirus family members like BatCoV RaTG13, batSL-CoV ZC45, and bat-SL-CoV ZXC21 (6-10). Characterization of SARS-CoV-2 genome, structural and non-structural protein, life cycle, and interaction with the host are important subjects for researchers to find the best targets for designing candidate vaccines and drugs (5, 11-15). Although several products have entered clinical trials that are in progress, currently there are no approved therapeutics, drugs, and vaccines against COVID-19 (16). Most of these therapeutics are designed based on the available data on SARS coronavirus, while our understanding of SARS-CoV-2 pathogenesis is limited (17).

One of the challenges about COVID-19 is its effect on different organs, showing its ability for interaction with similar receptors expressed in related cells. Detection of angiotensin-converting enzyme 2 (ACE2) as the main known receptor for SARS-CoV-2, which can be expressed in the lungs, heart, kidneys, endothelium, intestine, and brain, supports the reported multi-organ injury in the in- 
fected patients. These damages also could be explained indirectly by oxygen depletion and induction of severe inflammation in these tissues $(12,13,15)$. Analysis of histological changes in autopsy and biopsy of patients, together with clinical information and data as to the cellular and molecular immunology of COVID-19, will reveal a more complete picture of the infection and its pathogenesis. The current scoping review tries to synthesize early findings on the pathogenesis of SARS-CoV-2 to assess emerging therapies and vaccines by evaluating their impact based on the mechanism of pathogenicity. The study was designed due to the lack of any reliable protocols for the treatment of the disease and vaccines or other immunization drugs for its prevention.

\section{Methods}

In this review, the three databases of PubMed, Scopus, and google scholar were searched. In order to make this search extensive and sensitive, only the words "corona" and "immunology" were searched in the three databases, but this search was limited to studies from January 2020 until March, 15 2020. Quality assessment was performed and only thematic relevance was considered for the selection of the articles. To extract the results from the studies, the content thematic analysis method was used. In this method, the topics studied were coded in the articles and then classified into four main areas, including "Genome structure similarity to other coronaviruses", "virus entry inhibition and immune response", "vaccine and treatment targets", and "pathogensis".

Qualitative analysis was performed based on thematic content analysis and included the evaluation of overlap and coverage of content, the degree of consistency or inconsistency of the results, and the topics that have been most emphasized in the studies.

\section{Results}

Out of the 2250 articles retrieved, after deleting duplicates and reviewing their thematic relevance, 45 were selected for final analysis. Entry of SARS-CoV-2 into host cells and related components for interaction with the host were emphasized in seven studies (Table1). As summarized in Table 2, antibody-dependent enhancement, increased interaction of the virus with host cells through mutation of surface proteins, cytokine storm and inflammation, and diminished $\mathrm{T}$ lymphocytes count were reported as possible mechanisms for the virus immunopathogenesis.

In the studies proposing vaccines and other immunization routes against COVID-19, monoclonal neutralizing antibodies (5 studies), CoV fusion/entry inhibitors (1 study),

\begin{tabular}{|c|c|c|}
\hline Mechanisms & $\begin{array}{c}\text { Viral } \\
\text { Components-Host } \\
\text { Cells }\end{array}$ & Reference \\
\hline Virus entry & S protein-ACE2 & (18) \\
\hline Virus entry & $\begin{array}{l}\text { Receptor binding } \\
\text { domain (RBD)-ACE2 }\end{array}$ & (19) \\
\hline Virus entry & $\begin{array}{c}\text { RBD (residue } \\
\text { 493)-ACE2 (Lys31) }\end{array}$ & (3) \\
\hline Virus entry & S1 subunit-ACE2 & \multirow{2}{*}{$(14)$} \\
\hline Membrane fusion & $\begin{array}{l}\text { Six-helical bundle } \\
\text { (6-HB)-host cell } \\
\text { membrane }\end{array}$ & \\
\hline $\begin{array}{l}\text { Virus entry and } \\
\text { spread }\end{array}$ & S2-TMPRSS2 protease & (20) \\
\hline Virus entry & $\begin{array}{c}\text { S1 RBD (unique } \\
\text { phenylalanine } \\
\text { F486)-ACE2 } \\
\text { (hydrophobic pocket) }\end{array}$ & (21) \\
\hline Virus entry & $\begin{array}{l}\text { Linear surface exposed } \\
\text { non-glycosylated } \\
\text { epitopes in RBD-ACE2 }\end{array}$ & $(22)$ \\
\hline
\end{tabular}

and epitop based vaccines (5 studies) were presented (Table 3). Drugs against the infection were reported in six studies (Table 4). These drugs could target fusion, entry, replication, and spread of the virus (Figure 1). While the results of clinical trials for candidate vaccines and therapeutics were not presented in any of the published articles, a list of nine ongoing trials is presented in this review (Figure 2).

\section{Discussion}

4.1. Genetic Structure and Similarity of COVID-19 with Other Coronaviruses

At the amino acid level, SARS-CoV-2 is quite similar to SARS-CoV and has a genome size of $\sim 30$ kilobases $(24,34)$. SARS-CoV-2 belongs to Betacoronaviruses with $96.2 \%$ similarity, in a clade composed of MERS-CoV (about 50\% sequence homology), SARS-like bat CoV (96.2\%), and SARS$\operatorname{CoV}(80 \%-88.2 \%$ sequence identity with $98 \%$ coverage) (11, 21, 34-36). The similarity between SARS-CoV-2 and RaTG13 was estimated as $96.3 \%(10,12,18)$. The closest homolog of SARS-CoV-2 is a SARS-like coronavirus isolated from bat (MG772933.1) with 87.99\% at 99\% coverage (21). Whole spike glycoprotein and its receptor-binding domain (RBD) share $76 \%$ and $72 \%$ sequence identity with SARS-CoV, respectively, and a total of 22 predicated $\mathrm{N}$-glycosylation sites found in the spike glycoprotein of SARS-CoV-2, which are shared by SARS-CoVs (21).

The virus contains 14 open reading frames (ORF) that encode 27 proteins. The ORF1AB and ORF1A genes encode 15 


\begin{tabular}{|c|c|c|c|c|c|c|c|}
\hline \multicolumn{2}{|c|}{ Disorders } & \multicolumn{2}{|c|}{ Mechanisms } & \multicolumn{2}{|c|}{ Viral Structure } & Host Target & Reference \\
\hline \multicolumn{2}{|c|}{$\begin{array}{l}\text { Sustained inflammation, } \\
\text { lymphopenia, and/or cytokine } \\
\text { storm }\end{array}$} & \multicolumn{2}{|c|}{$\begin{array}{l}\text { Antibody dependent } \\
\text { enhancement (ADE) through prior } \\
\text { exposure to othe SARS-CoVs }\end{array}$} & \multicolumn{2}{|c|}{ Not declared } & Immune system & (13) \\
\hline \multicolumn{2}{|c|}{$\begin{array}{l}\text { Infection enhances the cleavage } \\
\text { efficiency }\end{array}$} & \multicolumn{2}{|c|}{$\begin{array}{l}\text { An insertion sequence in the spike } \\
\text { protein of SARS-CoV-2 }\end{array}$} & \multicolumn{2}{|c|}{$\begin{array}{l}\text { SPRR insertion in the S1/S2 } \\
\text { protease cleavage sites of } \\
\text { SARS-CoV-2 spike protein }\end{array}$} & $\begin{array}{l}\text { pulmonary alveoli, intestinal and } \\
\text { esophagus epithelium were also } \\
\text { the target tissues of SARS-CoV-2 }\end{array}$ & $(12)$ \\
\hline \multicolumn{2}{|c|}{$\begin{array}{l}\text { Inflammation and severe lung } \\
\text { pathology }\end{array}$} & \multicolumn{2}{|c|}{$\begin{array}{l}\text { Activation of Th1, high expression } \\
\text { of GM-CSF and IL-6 by pathogenic } \\
\text { monocytes }\end{array}$} & \multicolumn{2}{|c|}{ Not declared } & $\begin{array}{l}\text { Iper } 1 \text { lymphocytes and } \\
\text { Immatory CD14+CD16+ } \\
\text { monocytes }\end{array}$ & $(15)$ \\
\hline \multicolumn{2}{|c|}{ Severe respiratory illness } & \multicolumn{2}{|c|}{$\begin{array}{l}\text { Diminished } \mathrm{T} \text { lymphocytes and } \\
\text { elevated cytokines }\end{array}$} & \multicolumn{2}{|c|}{ Not declared } & Lung tissue & (6) \\
\hline \multicolumn{2}{|c|}{$\begin{array}{l}\text { Acute respiratory distress } \\
\text { syndrome (ARDS) and } \\
\text { multiple-organ dysfunction } \\
\text { syndrome }\end{array}$} & \multicolumn{2}{|c|}{$\begin{array}{l}\text { Cytokine storm, T cell exhaustion, } \\
\text { IL-10 overexpression }\end{array}$} & \multicolumn{2}{|c|}{ Not declared } & T cells & (23) \\
\hline & Product & $\begin{array}{l}\text { Steps of the } \\
\text { Pathogenesis }\end{array}$ & Vir & Cycle & The Viral Targets & $\begin{array}{l}\text { Proposed Application } \\
\text { (Candidate Vaccines \& } \\
\text { Therapeutics) }\end{array}$ & Reference \\
\hline $\mathbf{1}$ & $\begin{array}{l}\text { Monoclonal neutralizing } \\
\text { antibodies }\end{array}$ & Entry & & sion & Spike glycoprotein (S) & Vaccines & (5) \\
\hline 2 & $\begin{array}{l}\text { CoV fusion/entry } \\
\text { inhibitors }\end{array}$ & Fusion & & sion & $\begin{array}{l}\text { HR2 and HR1 domain in } \\
\text { spike protein }\end{array}$ & Vaccines & $(14)$ \\
\hline 3 & Epitop based vaccine & Entry and Release & Fusior & & $\begin{array}{c}\text { Spike }(\mathrm{S}) \text { and } \\
\text { nucleocapsid }(\mathrm{N})\end{array}$ & Vaccine & $(24)$ \\
\hline 6 & Neutralizing antibody & Entry & & & $S$ protein & Vaccine & (20) \\
\hline 7 & Monoclonal antibody & Immuopathology & & & $\begin{array}{l}\text { GM-CSF or interleukin } 6 \\
\text { receptor }\end{array}$ & Vaccine & $(15)$ \\
\hline 11 & $\begin{array}{l}\text { Potential B and T cells } \\
\text { epitopes }\end{array}$ & Entry & Attachi & nd fusion & $S$ protein & Vaccine & $(26)$ \\
\hline 12 & $\begin{array}{l}\text { Potential neutralizing } \\
\text { antibodies, B-cell } \\
\text { epitopes, and peptide } \\
\text { vaccine candidates }\end{array}$ & Spread & Viral en & $\begin{array}{l}\text { dimmune } \\
\text { ise }\end{array}$ & $\begin{array}{l}\text { S, ORF1ab, ORF3a, M } \\
\text { protein }\end{array}$ & Vaccine & (27) \\
\hline 14 & $\begin{array}{l}\text { Putative B and T cells } \\
\text { epitopes }\end{array}$ & $\begin{array}{l}\text { Entry, fusion, and } \\
\text { assembly }\end{array}$ & Induc & $\begin{array}{l}\text { immune } \\
\text { ise }\end{array}$ & $\mathrm{S}, \mathrm{E}$, and $\mathrm{M}$ & Vaccine & (28) \\
\hline 15 & $\begin{array}{l}\text { Synthetic long peptide } \\
\text { vaccine }\end{array}$ & Entry and assembly & $\begin{array}{r}\text { Induct } \\
\mathrm{CD} 8^{+}\end{array}$ & $\begin{array}{l}\mathrm{CD} 4^{+} \text {and } \\
\text { mmune } \\
\text { ise }\end{array}$ & S and $M$ proteins & Vaccine & (29) \\
\hline 16 & Putative epitope vaccines & $\begin{array}{l}\text { Entry, processing, } \\
\text { assembly }\end{array}$ & Interac & th $\mathrm{B}$ and $\mathrm{T}$ & ORF1, N, S & Vaccine & (23) \\
\hline 19 & $\begin{array}{l}\text { Linear surface-exposed } \\
\text { epitopes }\end{array}$ & Entry & Vira & achment & Spike protein & Vaccines & $(22)$ \\
\hline
\end{tabular}

non-structural proteins (NSPs). The viral genome also encodes S, E, M, and N structural proteins and accessory proteins 3a, 3b, p6, 7a, 7b, 8b, 9b, and orf14. Results showed $>90 \%$ identity in proteins $\mathrm{E}, \mathrm{M}$, and $\mathrm{N}$ and accessory proteins 7 and Orf14, of which E protein was more conserve (98.7\% identity). Based on the phylogenetic analyses, it was shown that ppiab, ppia, envelope, matrix, accessory pro- tein 7a, and nucleocapsid genes of SARS-CoV-2 show high similarity with SARS-like bat CoVs (34).

In a study that compared homology of bat-SL-CoVZC45 and bat-SL-CoV ZXC21 with SARS-CoV-2, 87.9\% and $87.2 \%$ identity was determined at the genomic level, respectively. The lowest identity was related to $S$ protein $(64 \%-68 \%$ and 93\% homology for the S1 and S2 subunits, respectively) (37, 


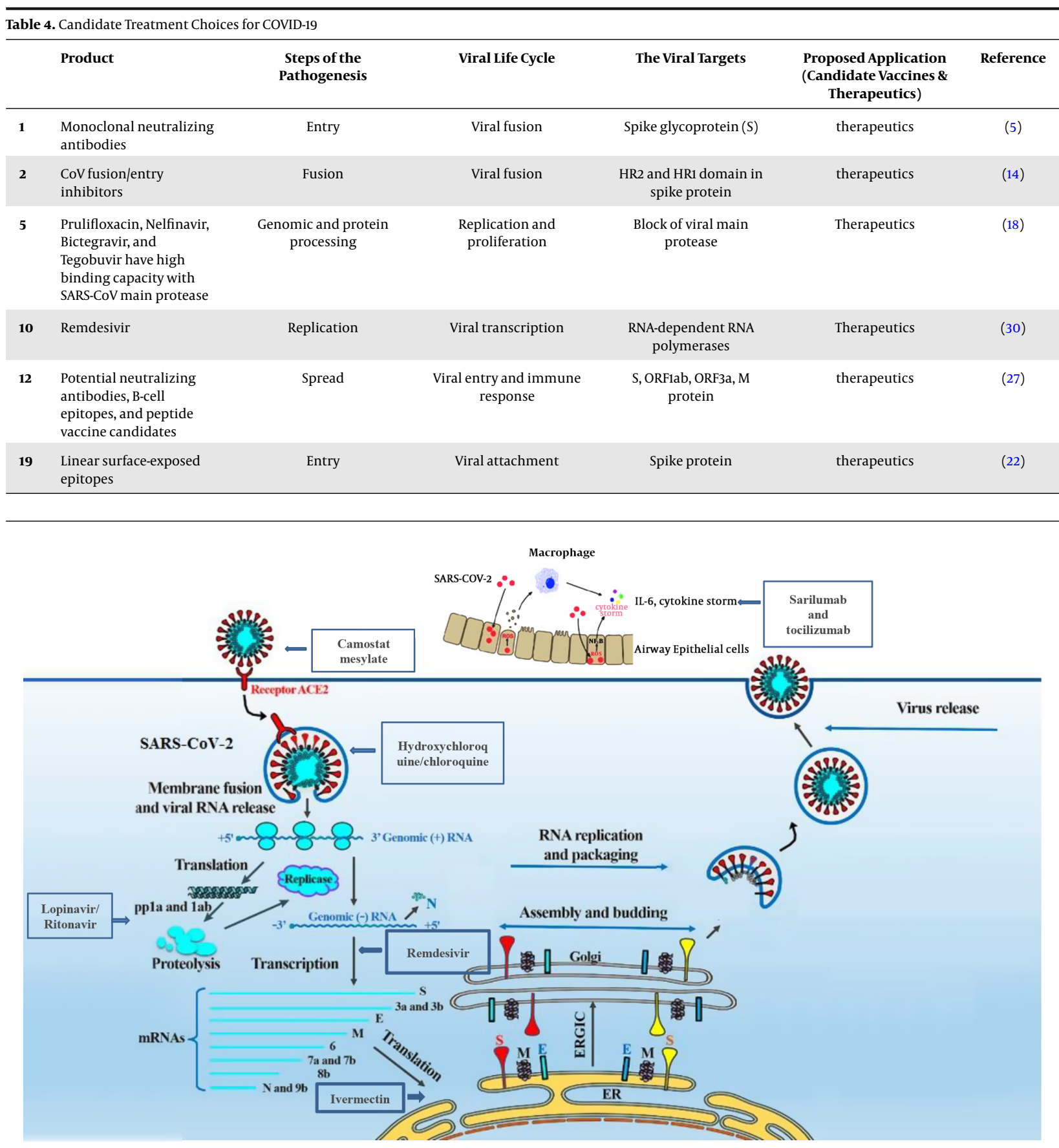

Figure 1. Interaction of candidate drugs with severe acute respiratory syndrome Coronavirus-2 at different steps of its life cycle

38). Other mutations, except for those detected in the spike protein contained within some regions of the RBD, are observed in NSP3 and NSP2 and some of the accessory proteins. In a study by Shu et al., a higher substitution rate of ORF1ab and spike protein was shown, most of which were similar to bat-CoV-RaTG13, pangolin-CoV, and SARS viruses.
Substitution in spike-S1 was characterized in SARS-CoV2 specifically. Higher affinity of SARS-CoV-2 spike protein to the wild-type spike, containing the V354F amino acid substitution was proposed as the cause of its super infectivity (39). Bioinformatics analysis showed that an insertion in the spike protein of SARS-CoV-2 could increase its cleav- 


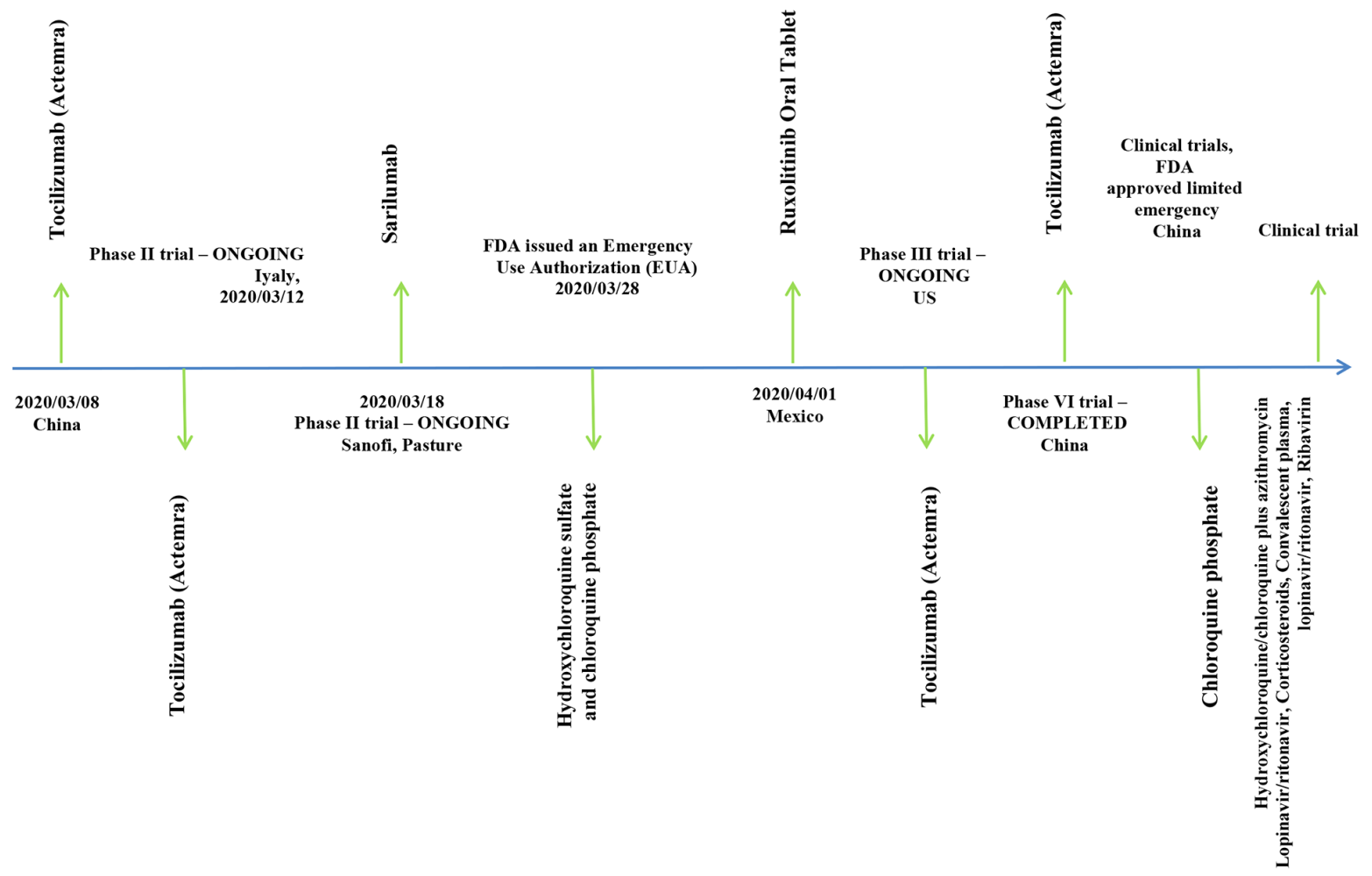

Figure 2. Upcoming potential therapeutic candidates for COVID-19. More details can be found in (31-33)

age by S1/S2 protease, a phenomenon that could explain its higher pathogenicity. Compared with SARS-CoV, the insertion sequence small proline-rich protein (SPRR) at the S1/S2 cleavage site, which could be used as the more appropriate substrate for transmembrane protease serine(TMPRSS) protease, could increase the cleavage rate of the $S$ protein that enhances its infectivity. While no amino acid substitutions were detected in the receptor-binding motifs that are responsible for interaction with ACE2 and other receptors for the virus entry, some mutations were characterized in other regions of the RBD (39).

Moreover, coexpression of ACE2 and TMPRSS protease in pulmonary alveoli, intestinal epithelium, esophagus, and epithelium of the colon explained the ability of this virus to infect several tissues (12). The spread of the virus to these tissues can support recent findings about a long time shedding of the virus in the stool of patients at the convalescent phase. Deletion in the complete frame of the protein $8 \mathrm{a}$, and deletion and insertion of several amino acids shown in proteins $3 \mathrm{~b}$ and $8 \mathrm{~b}$, respectively, are among other mutations reported in SARS-CoV-2 $(8,34)$. Further studies are needed to examine the effects of these mutations on the infection rate of SARS-CoV-2 in different populations, the severity of the pathogenesis, and interference with the induction of immune response.

\subsection{Cellular Entry of Virus to the Host Cell}

Currently, different theories have been presented about the cellular entry of SARS-CoV-2 to the host cell. There are some viral components and host receptors that are described for this virus (Table 1). It was shown that this virus does not use some specified receptors, like aminopeptidase $\mathrm{N}$ and dipeptidyl peptidase 4, like other coronaviruses, but can exploit angiotensin-converting enzyme 2 (ACE2) on the surface of host cells for its entry $(2,18)$. SARSCoV-2 can promote interaction with the host cell receptor through the receptor-binding domain (RBD) on its spike protein. This receptor is specific for lineage B beta coronaviruses (i.e. SARS-CoV and SARS-CoV-2). Protease treatment can enhance the ACE2 entry of clade 2 RBD (19).

A cellular protease known as TMPRSS2 seems to be responsible for spike protein priming that could facilitate its fusion, entry, and/or progression of the infection in infected patients $(2,3,10,14,18-22)$. SARS-CoV-2 recognizes ACE2 in a variety of animal species that could serve as intermediate hosts for humans. 
Some RBD residues on the spike protein are critical for interaction with ACE2, which could be exploited for drug design. Among them, N-terminal domain (aa14-305), receptor-binding domain (aa319-541), receptorbinding motif (aa437-508) in S1 subunit, (aa14-685) and fusion peptide (aa788-806), HR1 (aa912-984), HR2 (aa11631213), transmembrane domain (aa1214-1237), and a cytoplasmic domain (aa1238-1273) in S2 subunit (aa686-1273), are involved in the fusion mechanism with ACE2 receptor on host cells (14).

Mutation in some of these residues, such as Gln493 in RDB of SARS-CoV-2, could interfere with its interaction with the human ACE2 receptor, suggesting the involvement of virus-binding hotspots on this receptor $(3,22)$. It was shown that hydrophobic amino acid L472 is also important for the interaction between RBD and ACE2 that is involved in the virus entry into cells (21). There is a lack of data about other binding domains on SARS-CoV-2 and host cell receptors to describe difference in organ tropism and susceptibility to the infection at different age groups.

\subsection{Pathogenesis and Host Immune Response}

Several mechanisms have been proposed for SARS-CoV2 pathogenesis (Table 2). This virus is able to promote lymphopenia and sustain inflammation (13). Analysis of lung autopsy of infected patients with SARS-CoV-2 showed large numbers of pathogenic immune cells that suggested immune-mediated damage as the main cause of organ dysfunction and death in these patients. Occurrence of severe pulmonary inflammation and cytokine storm can be promoted by SARS-CoV-2 through the activation of $\mathrm{CD} 4^{+} \mathrm{T}$ lymphocytes that generate GM-CSF and induce $\mathrm{CD} 14^{+} \mathrm{CD} 16^{+}$ monocytes that can produce high amounts of IL-6 (15). Acute respiratory distress syndrome, shock, hypoxemia, acute kidney injury, acute liver injury, and cardiac injury, as well as secondary infection by bacteria and fungi, can occur during COVID-19. Laboratory findings, including lymphopenia (lymphocyte count decreases significantly in severe cases), elevated levels of alanine aminotransferase, lactate dehydrogenase, high-sensitivity C-reactive protein, and ferritin in severe cases, higher concentrations of IL$2 \mathrm{R}$, TNF- $\alpha$, and IL-10, lower absolute number of total T lymphocytes, and lower expression levels of IFN- $\gamma$, an antiinflammatory cytokine, by $\mathrm{CD}^{+}{ }^{+} \mathrm{T}$ cells, could support the noted extensive organ injuries in severe cases of COVID-19, especially in elderly patients ( $\geq 60$ years of age) and those requiring intensive care unit (ICU) care $(6,40)$.

\subsection{Vaccination and Treatment}

Scientists are working on different targets to design a vaccine or provide therapies against COVID-19 (Tables 3 and
4). Some of these candidates can affect different steps of the virus entry. Among the proposed candidates, a computational analysis showed 405 likely T-Cell epitopes on $\mathrm{S}$ protein, with strong MHC-I and MHC-II presentation scores and 2 potential neutralizing B-Cell epitopes (27). The capacity of the spike protein and the ability of its related epitopes such as T-cell (Good MHC presenter) and B-cell epitopes was also described by other studies $(5,11)$.

TMPRSS2 inhibition is the other target that can block the entry of the virus into host cells (20). SARS-CoV-2 employs this protease for $S$ protein priming, which is necessary for interaction with ACE2. Moreover, the design of neutralizing antibodies interfering with two electrostatic clips predicted at the interface between ACE2 and the SARS-CoV spike protein RBD was suggested in a study $(22,41)$. RBD and ACE2 $\mathrm{n}$ are the essential steps for virus attachment and entry into the host cell. Characterization of unique amino acid residues on the S protein, like phenylalanine F486 that is placed in its flexible loop that strongly interacts with F28 in ACE2, increased hopes for the production of effective treatments (21).

The design and construction of antibodies as treatment options was also proposed by other studies. In a study, the production of a high-affinity antibody equiped with lipophilic structure was suggested against viroporin channels. This antibody could cause virion impairment preventing its attachment to human cell membrane receptors (25).

Induction of immune system elicited by candidate vaccines and medications was proposed as an alternative option to combat COVID-19. In a study by Qamar et al., reverse vaccinology technique was used, which predicted 23 linear B cell and $16 \mathrm{~T}$ cell epitopes of SARS-CoV-2 surface glycoprotein, envelope protein, and membrane glycoprotein with diverse antigenic potentials through immunoinformatics approaches. The study also suggested two antigenic epitopes for MHC class I and II (28).

In a similar study by Baruah et al., immunoinformatics approach was used to identify cytotoxic Tlymphocyte(CTL) and B cell epitopes in SARS-CoV-2 surface glycoprotein (26). In a study by Bojin et al., doing population-based vaccinomics was proposed for vaccine design against SARS-CoV2. Accordingly, sequences of spike and membrane proteins were analyzed, and multiepitope peptide vaccine candidates that can potentially prompt both $\mathrm{CD} 8^{+}$and $\mathrm{CD} 4^{+}$cellmediated immune response with the specified tendency to HLA-type of each population was suggested (29). In a study by Zhou et al., the production of GM-CSF by activated TCD $4^{+}$ cells following infection with SARS-CoV-2 and interleukin-6 secretion by the induced inflammatory $\mathrm{CD} 14^{+} \mathrm{CD} 16^{+}$monocytes was considered as the mainstay of severe pulmonary inflammation and cytokine storm (15). 
In a study by Zhu et al., patterns of mutations in SARSCoV-2 strains and their possible effects on the immune vulnerability of a population was studied. The study was aimed to show the ability of viral immunogenic epitopes with the lowest mutations to induce class I and II MHC presentation to properly elicit $\mathrm{CD} 8^{+}$and $\mathrm{CD} 4^{+} \mathrm{T}$ cell responses. The results of this study showed the existence of some mutations among different strains that could alter the immune vulnerability landscape of this virus, which should be considered in the development of vaccines and therapies (23).

Main protease (also known as nsp3) and nucleotide analogues are among the other targets for the design of drugs or vaccines against COVID-19. In a study by Li et al., a similarity of $96.1 \%$ was detected between the sequences of SARS-CoV-2 and SARS-CoV main proteases (18). The study suggested four small molecular drugs as promising candidates with high binding capacity to SARS-CoV main protease; these drugs included including Prulifloxacin, Bictegravir, Nelfinavir, and Tegobuvi. In a study by Gordon, it was shown that nucleotide analogues can affect RNAdependent RNA polymerases (RdRp) by inhibition of RNA synthesis (30). The researchers proposed the same strategy for the design of equivalent MERS-CoV antiviral constructs against SARS-CoV-2.

WHO, CDC, and other international medical centers and infectious diseases societies are updating the latest news about designing new drugs and vaccines against COVID-19. As shown in Figure 1, these drugs can block the virus entry (Camostat mesylate), $S$ protein/ACE2 interaction and membrane fusion (umifenovir, also known as Arbidol), protease inhibotors, viral RNA transcription (remdesivir), cytokine storm (sarilumab and tocilizumab, which block IL-6 production), and membrane fusion (hydroxychloroquine/chloroquine that change the $\mathrm{pH}$ of acidic intracellular organelles, including endosomes/lysosomes, which are essential for the membrane fusion, and viral replication) (Ivermectin, through its nuclear transport inhibitory activity). Most of these drugs are subjected to a global clinical trials by the WHO, which is known as a megatrial called SOLIDARITY.

The development of a vaccine seems to be the most effective strategy for the prevention of COVID-19. Recent supportive data about the protective effects of plasma from curred patients at the convalescent phase increased promise for vaccine development. While a review of reports about candidate COVID-19 vaccines is beyond the scope of this review, we tried to present the main products that are at the clinical trial stage (Figure 2) (42).

\section{Footnotes}

Authors' Contribution: Leila Azimi: data extraction from related papers, designing tables, writing the introduction and results sections. Abdollah Karimi: study conception, managing the manuscript preparation, and editing the written manuscript. Fatemeh Fallah: microbial counselor. Shahnaz Armin: infectious counselor. Roxana Mansour Ghanaie: methodology counselor. Sedigheh Rafiei Tabatabaei: methodology counselor. Saeid Maham: data extraction. Maryam Rajabnejad: data extraction. Seyed Alireza Fahimzad: infectious counselor. Fariba Shirvani: data extraction. Masoud Alebouyeh: data analysis, designing tables, writing the discussion section and revising the manuscript. Armin Shirvani: searching the papers, designing and writing the methodology and abstract, and data extraction

Conflict of Interests: No conflict of interest.

Funding/Support: This study was supported by a grant from Pediatric Infections Research Center, Research Institute for Children's Health, Shahid Beheshti University of Medical Sciences, Tehran, Iran.

\section{References}

1. Worldometer. COVID-19 coronavirus pandemic. 2020. Available from: https://www.worldometers.info/coronavirus.

2. Lee P, Hu Y, Chen P, Huang Y, Hsueh P. Are children less susceptible to COVID-19? Journal of Microbiology, Immunology and Infection. 2020. doi: 10.1016/j.jmii.2020.02.011.

3. Wan Y, Shang J, Graham R, Baric RS, Li F. Receptor Recognition by the Novel Coronavirus from Wuhan: an Analysis Based on DecadeLong Structural Studies of SARS Coronavirus. J Virol. 2020;94(7). doi: 10.1128/JVI.00127-20. [PubMed: 31996437]. [PubMed Central: PMC7081895].

4. Adhikari SP, Meng S, Wu YJ, Mao YP, Ye RX, Wang QZ, et al. Epidemiology, causes, clinical manifestation and diagnosis, prevention and control of coronavirus disease (COVID-19) during the early outbreak period: a scoping review. Infect Dis Poverty. 2020;9(1):29. doi: 10.1186/s40249-020-00646-x. [PubMed: 32183901]. [PubMed Central: PMC7079521].

5. Goo J, Jeong Y, Park YS, Yang E, Jung DI, Rho S, et al. Characterization of novel monoclonal antibodies against MERS-coronavirus spike protein. Virus Res. 2020;278:197863. doi: 10.1016/j.virusres.2020.197863. [PubMed: 31945421]. [PubMed Central: PMC7114870].

6. Chen G, Wu D, Guo W, Cao Y, Huang D, Wang H, et al. Clinical and immunologic features in severe and moderate forms of Coronavirus Disease 2019. medRxiv. 2020.

7. Chen Y, Liu Q, Guo D. Emerging coronaviruses: Genome structure, replication, and pathogenesis. J Med Virol. 2020;92(4):418-23. doi: 10.1002/jmv.25681. [PubMed: 31967327].

8. Coutard B, Valle C, de Lamballerie X, Canard B, Seidah NG, Decroly E. The spike glycoprotein of the new coronavirus 2019-nCoV contains a furin-like cleavage site absent in CoV of the same clade. Antiviral Res. 2020;176:104742. doi: 10.1016/j.antiviral.2020.104742. [PubMed: 32057769]. [PubMed Central: PMC7114094].

9. Li X, Song Y, Wong G, Cui J. Bat origin of a new human coronavirus: there and back again. Sci China Life Sci. 2020;63(3):461-2. 
doi: 10.1007/s11427-020-1645-7. [PubMed: 32048160]. [PubMed Central: PMC7088771].

10. Paraskevis D, Kostaki EG, Magiorkinis G, Panayiotakopoulos G, Sourvinos G, Tsiodras S. Full-genome evolutionary analysis of the novel corona virus (2019-nCoV) rejects the hypothesis of emergence as a result of a recent recombination event. Infect Genet Evol.2020;79:104212. doi: 10.1016/j.meegid.2020.104212. [PubMed: 32004758]. [PubMed Central: PMC7106301].

11. Malik YS, Sircar S, Bhat S, Sharun K, Dhama K, Dadar M, et al. Emerging novel coronavirus (2019-nCoV)-current scenario, evolutionary perspective based on genome analysis and recent developments. Vet Q. 2020;40(1):68-76. doi: 10.1080/01652176.2020.1727993. [PubMed: 32036774]. [PubMed Central: PMC7054940].

12. Meng T, Cao H, Zhang H, Kang Z, Xu D, Gong H, et al. The insert sequence in SARS-CoV-2 enhances spike protein cleavage by TMPRSS. bioRxiv. 2020.

13. Tetro JA. Is COVID-19 receiving ADE from other coronaviruses? Microbes Infect. 2020;22(2):72-3. doi: 10.1016/j.micinf.2020.02.006. [PubMed: 32092539]. [PubMed Central: PMC7102551].

14. Xia S, Zhu Y, Liu M, Lan Q, Xu W, Wu Y, et al. Fusion mechanism of 2019-nCoV and fusion inhibitors targeting HR1 domain in spike protein. Cell Mol Immunol. 2020. doi: 10.1038/s41423-020-0374-2. [PubMed: 32047258].

15. Zhou Y, Fu B, Zheng X, Wang D, Zhao C, Qi Y, et al. Aberrant pathogenic GM-CSF+ T cells and inflammatory CD14+CD16+ monocytes in severe pulmonary syndrome patients of a new coronavirus. bioRxiv. 2020.

16. Li Y, Zhang J, Wang N, Li H, Shi Y, Guo G, et al. Therapeutic Drugs Targeting 2019-nCoV Main Protease by High-Throughput Screening. bioRxiv. 2020.

17. XiaoweiLi M, Geng Y, Peng L, Meng S. Molecular immune pathogenesis and diagnosis of COVID-19. Journal of Pharmaceutical Analysis. 2020;10(2):102-8. doi: 10.1016/j.jpha.2020.03.001.

18. Zhou P, Yang XL, Wang XG, Hu B, Zhang L, Zhang W, et al. A pneumonia outbreak associated with a new coronavirus of probable bat origin. Nature. 2020;579(7798):270-3. doi: 10.1038/s41586-020-2012-7. [PubMed: 32015507]. [PubMed Central: PMC7095418].

19. Letko MC, Munster V. Functional assessment of cell entry and receptor usage for lineage $\mathrm{B} \beta$-coronaviruses, including 2019-nCoV. bioRxiv. 2020.

20. Hoffmann M, Kleine-Weber H, Krüger N, Mueller MA, Drosten C, Pöhlmann S. The novel coronavirus 2019 (2019-nCoV) uses the SARScoronavirus receptor ACE2 and the cellular protease TMPRSS2 for entry into target cells. BioRxiv. 2020.

21. Chen Y, Guo Y, Pan Y, Zhao ZJ. Structure analysis of the receptor binding of 2019-nCoV. Biochem Biophys Res Commun. 2020. doi: 10.1016/j.bbrc.2020.02.071. [PubMed: 32081428]. [PubMed Central: PMC7092824].

22. Zhou D, Qi R, Zhang W. Accessible Surface Glycopeptide Motifs on Spike Glycoprotein of 2019-nCoV: Implications on Vaccination and Antibody Therapeutics. Preprints. 2020.

23. Zhu J, Kim J, Xiao X, Wang Y, Luo D, Chen R, et al. Profiling the immune vulnerability landscape of the 2019 Novel Coronavirus. bioRxiv. 2020. doi: 10.20944/preprints202002.0167.v1.

24. Ahmed SF, Quadeer AA, McKay MR. Preliminary Identification of Potential Vaccine Targets for the COVID-19 Coronavirus (SARS-CoV-2) Based on SARS-CoV Immunological Studies. Viruses. 2020;12(3). doi 10.3390/v12030254. [PubMed: 32106567].

25. Tozzi A. Dewetting antibodies against viroporins might contribute to decrease 2019-nCOV infection spread. viXra. 2020. doi: 10.13140/RG.2.2.31113.60001.

26. Baruah $\mathrm{V}$, Bose $\mathrm{S}$. Immunoinformatics-aided identification of $\mathrm{T}$ cell and B cell epitopes in the surface glycoprotein of 2019-nCoV. J Med Vi- rol.2020;92(5):495-500. doi: 10.1002/jmv.25698. [PubMed: 32022276].

27. Fast E, Chen B. Potential T-cell and B-cell Epitopes of 2019-nCoV. bioRxiv. 2020.

28. Qamar MT, Shahid F, Ali U, Fareed AZ, Chen L. Structural modeling and conserved epitopes prediction against SARS-COV-2 structural proteins for vaccine development. Research Square. 2020.

29. Bojin F, Gavriliuc O, Margineanu M, Paunescu V. Design of an EpitopeBased Synthetic Long Peptide Vaccine to Counteract the Novel China Coronavirus (2019-nCoV). Preprints. 2020.

30. Gordon CJ, Tchesnokov EP, Feng JY, Porter DP, Gotte M. The antiviral compound remdesivir potently inhibits RNA-dependent RNA polymerase from Middle East respiratory syndrome coronavirus. J Biol Chem. 2020;295(15):4773-9. doi: 10.1074/jbc.AC120.013056. [PubMed: 32094225]. [PubMed Central: PMC7152756].

31. ClinicalTrialsArena. Coronavirus: Chloroquine yields positive data in Covid-19 trial. 2020. Available from: https://www.clinicaltrialsarena. $\mathrm{com} /$ news/coronavirus-covid-19-choroquine-data.

32. World Health Organization. Novel-coronavirus. 2020. Available from https://www.who.int/blueprint/priority-diseases/key-action/novelcoronavirus/en/.

33. ClinicalTrialsArena. Coronavirus treatment: Vaccines/drugs in the pipeline for COVID-19. 2020. Available from: https://www. clinicaltrialsarena.com/analysis/coronavirus-mers-cov-drugs.

34. Wu A, Peng Y, Huang B, Ding X, Wang X, Niu P, et al. Genome Composition and Divergence of the Novel Coronavirus (2019nCoV) Originating in China. Cell Host Microbe. 2020;27(3):325-8. doi: 10.1016/j.chom.2020.02.001. [PubMed: 32035028]. [PubMed Central: PMC7154514]

35. Goh GK, Dunker AK, Foster JA, Uversky VN. Rigidity of the Outer Shell Predicted by a Protein Intrinsic Disorder Model Sheds Light on the COVID-19 (Wuhan-2019-nCoV) Infectivity. Biomolecules. 2020;10(2). doi: 10.3390/biom10020331. [PubMed: 32092911]. [PubMed Central: PMC7072294].

36. Wei X, Li X, Cui J. Evolutionary perspectives on novel coronaviruses identified in pneumonia cases in China. Natl Sci Rev. 2020;7(2):23942. doi: 10.1093/nsr/nwaa009. [PubMed: 32288962]. [PubMed Central: PMC7107983].

37. Chan JF, Kok KH, Zhu Z, Chu H, To KK, Yuan S, et al. Genomic characterization of the 2019 novel human-pathogenic coronavirus isolated from a patient with atypical pneumonia after visiting Wuhan. Emerg Microbes Infect. 2020;9(1):221-36. doi: 10.1080/22221751.2020.1719902. [PubMed: 31987001]. [PubMed Central: PMC7067204]

38. Li R, Qiao S, Zhang G. Analysis of angiotensin-converting enzyme 2 (ACE2) from different species sheds some light on cross-species receptor usage of a novel coronavirus 2019-nCoV. J Infect. 2020;80(4):46996. doi: 10.1016/j.jinf.2020.02.013. [PubMed: 32092392]. [PubMed Central: PMC7127620].

39. Shu C, Huang X, Brosius J, Deng C. Exploring Potential Super Infection in SARS-CoV2 by Genome-Wide Analysis and Receptor-Ligand Docking. Preprints. 2020.

40. Diao B, Wang C, Tan Y, Chen X, Liu Y, Ning L, et al. Reduction and functional exhaustion of T cells in patients with coronavirus disease 2019 (COVID-19). Medrxiv. 2020.

41. Li W. Structural Identification of the Electrostatic Hot Spots for Severe Acute Respiratory Syndrome Coronavirus Spike Protein to Be Complexed with Its Receptor ACE2 and Its Neutralizing Antibodies. Preprints. 2020

42. Sanders JM, Monogue ML, Jodlowski TZ, Cutrell JB. Pharmacologic Treatments for Coronavirus Disease 2019 (COVID-19): A Review. JAMA. 2020. doi: 10.1001/jama.2020.6019. 